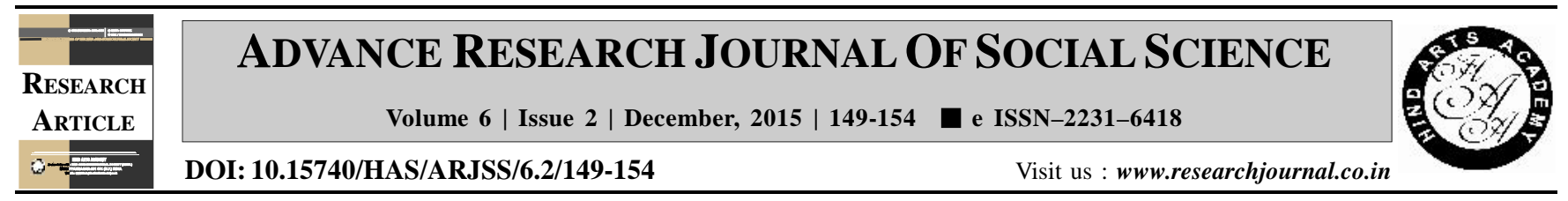

\title{
Correlates of utility perception of Krushi patrika by the respondents
}

M.G. Jambhale, N.J. Chikhale and A.N. Deshmukh*

Department of Extension Education, Shri Shivaji Agriculture College, AMRAVATI (M.S.) INDIA

\begin{tabular}{lll}
\multicolumn{2}{l}{ ARTICLE INFO : } \\
\hline Received & $:$ & 25.06 .2015 \\
Revised & $:$ & 15.10 .2015 \\
Accepted & $:$ & 28.10 .2015
\end{tabular}

KEY WORDS :

Utility perception Krushipatrika, Respondents

\section{HOW TO CITE THIS ARTICLE :}

Jambhale, M.G., Chikhale, N.J. and Deshmukh, A.N. (2015). Correlates of utility perception of Krushi patrika by the respondents. Adv. Res. J. Soc. Sci., 6 (2) : $149-154$.

*Author for correspondence

\begin{abstract}
The present investigation was conducted in Amravati district in Maharasthra state. The main objective of the study was to assess the relationship of profile of respondents with utility perception. A structured interview schedule was used to collect data from 100 respondents who were reading Krushi patrika from last two years. The statistical methods and tests such as frequency, percentage, mean, standard deviation, coefficient of correlation and chi-square distribution were used for the analysis of data. The result of the study showed that annual income, extension contact and mass media utilization were found positively and significantly correlated with utility perception.
\end{abstract}

